\title{
Inactivation of pathogens in ecological sanitati
in Malawi: An observational follow up study
}

\section{Save Kumwenda ${ }^{1,2_{*}}$, Chisomo Msefula ${ }^{1}$, Wilfred Kadewa ${ }^{3}$, Davis James Makupe ${ }^{2}$, Bagrey Ngwira ${ }^{2}$, Tracy Morse ${ }^{2,4}$}

Date Received: 14-Jun-2018

Revision Received:23-Aug-2018 Date Accepted: 09-Sep-2018

1. University of Malawi, College of Medicine, P/Bag 360, Chichiri, Blantyre 3, Malawi

2. University of Malawi, The Polytechnic, P/Bag 303, Chichiri, Blantyre 3, Malawi

3. Lilongwe University of Agriculture and Natural Resources, P.O. Box 219, Lilongwe, Malawi

4. Department of Civil and Environmental Engineering, University of Strathclyde, Glasgow, UK

\section{Abstract}

Introduction

In Malawi, EcoSan sludge from ecological sanitation (EcoSan) latrines has been found to contain helminths, Salmonella and E. coli above WHO recommended levels making sludge unsuitable for direct handling and use on food crops. This research investigated survival of pathogens in EcoSan sludge with time after sealing the pit.

\section{Method}

An observational longitudinal follow-up study was conducted where EcoSan latrines were followed from August 2015 to July 2016 in Blantyre and Chikwawa in Southern Malawi. The study enrolled 51 latrines in total with 35 latrines [13 fossa alterna (FAs) and 22 urine diverting dry latrines (UDDLs) remaining at the end of study. Samples were collected five times from each latrine and examined for helminths, Salmonella and E. coli in the laboratory. Poisson regression was employed to assess factors that significantly contribute to pathogen die off at $\mathrm{p}<0.05$.

Results

Average concentrations of all pathogens investigated reduced over 12-month follow-up period except for Salmonella which increased. A. lumbricoides increased to 2.3 viable eggs during the second sampling and decreased to 0.4 viable eggs per gram after 12 months of follow-up. Time was the only consistent predictor for concentration of helminths. Type of latrine and location were not significant predictors of helminths concentration ( $\mathrm{p}>0.05$ ) However, Salmonella and E. coli colonies were significantly higher in UDDLs (Blantyre) than FAs (Chikwawa) $(\mathrm{p}<0.05)$.

Conclusion

Pathogen concentration was highest after recommended six months of storage posing a public health risk to those handling and using it for agriculture purposes. It is therefore recommended that the current guidelines be reviewed to suit Malawi context. A storage period of one year or more is recommended.

Key Words: sanitation, guidelines, safety, pathogens, sanitation, follow-up, risk, Malawi

\section{Introduction}

Human faeces contain different microorganisms including bacteria, viruses, protozoa and helminths which may be pathogenic if passed to a new host ${ }^{1}$. Once human faeces are passed in the environment, some organisms survive and the most persistent is Ascaris lumbricoides (A. lumbricoides) and for this reason, it is commonly used as the main indicator organism for safety of faecal matter ${ }^{2-5}$. Salmonella and E. coli are also used to indicate environmental contamination with faeces ${ }^{6}$. The World Health Organisation (WHO) estimates that about $24 \%$ of world's population is infected with soiltransmitted helminths (STHs) and these helminths are transmitted through faeces especially in areas with poor sanitation ${ }^{7}$. In 2010 , people were at risk of infection by various parasites, with 5, 346 at risk of hookworm infection, 5, 416 at risk of Ascaris lumbricoides (A. lumbricoides) infection and 5, 307 at risk of Trichuris trichiura infection ${ }^{8}$. STHs are a problem globally especially in Sub-Saharan Africa, America, China and East Asia'. In Malawi, in 2013, the average concentration of helminth eggs in one gram of sludge from Fossa Alternas
(FAs) and Urine Diverting Dry Latrines (UDDLs) ranged from 20 to 131 viable ova while total coliforms ranged from 500 to 580 colonies $^{4}$. The recommended number of helminth eggs in Ecological Sanitation (EcoSan) sludge is less than 1 viable egg per gram of EcoSan sludge if the sludge will be used for agriculture purposes ${ }^{10}$. According to the United States (US) Environmental Protection Agency (EPA) of 1997, the standard for Salmonella and E. coli is that there should be no detectable colonies per 50grams and no more than 100 Most Probable Number (MPN) respectively ${ }^{11}$. EcoSan is an environmentally-friendly sanitation technology that allows economic use of human excreta as manure after decomposition ${ }^{12}$. EcoSan promotes recycling of nutrients contained in excreta; thus enhancing food security and reducing need to rely on artificial fertilizers ${ }^{13}$. Most of the nutrients in artificial fertilizers are also present in human excreta and these include nitrogen, urea, potassium and phosphorous ${ }^{12,13}$. In Malawi, three types of EcoSan latrines are available: FAs, UDDLs, and Arborloos. The UDDL has twin pits which are built about one or more metres above 
ground and has a urine diverting system and a soak away pit while FA has twin pits which are dug up to 1.5 metres deep and does not have a urine diverting system. After one pit is full, it is covered with soil and household members start using the other one, making it a permanent latrine ${ }^{14}$. By 2001, over 10,000 households in Lilongwe, Salima, Machinga, Nkhotakota, Mzimba and Blantyre were practicing EcoSan. About $0.3 \%$ of total latrines in Malawi were EcoSan and promotion of such latrines is increasing ${ }^{4,15}$.

The Government of Malawi through National Health Research Agenda recognized safety of EcoSan sludge as a priority research area for the country ${ }^{16}$. This priority reflected lack of local research on safety of EcoSan humus, as evidence from other studies elsewhere indicate production of unsafe sludge from EcoSan latrines. Studies in rural Panama found that parasites still persisted in sludge from UDDLs after recommended six months of storage ${ }^{17,18}$. From literature, two different recommended storage times are found with some stating six months while others recommend at least a year ${ }^{4,19}$. Not only is pathogen die-off dependent on sludge achieving temperatures above $40^{\circ} \mathrm{C}$ and a moisture content of less than $25 \%{ }^{20}$ but is also dependent on practices during latrine use and other environmental conditions specific to location ${ }^{14}$. Effect of temperature and humidity are interdependent, for example, a study in South Africa found that at $60^{\circ} \mathrm{C}$, temperature was the only factor while at temperatures below $60^{\circ} \mathrm{C}$ low humidity became the critical factor for A. lumbricoides die-off. At temperatures of $30^{\circ} \mathrm{C}$ and below, A. lumbricoides eggs were not inactivated and at temperatures lower than $20^{\circ} \mathrm{C}$, eggs can remain viable for over a year irrespective of humidity ${ }^{21}$.

To investigate factors that lead to pathogen die-off, most studies used to inoculate indicator organism, Ascaris suum, into manure and/or faeces while mimicking conditions in latrines ${ }^{22-24}$. These studies have informed guidelines on operation of EcoSan latrines but few of these have been

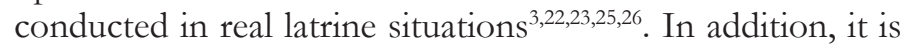
not appropriate to generalize conditions for recommended pathogen die-off due to environmental changes ${ }^{2}$. This research therefore investigated pathogen survival in EcoSan sludge from EcoSan latrines with respect to time. Due to the existing practices of EcoSan users which affect stability of moisture reduction and increase in $\mathrm{pH}$ through addition of ash for pathogen die-off ${ }^{14}$, this study concentrated on the storage time after sealing the pit. The target pathogens were A. lumbricoides, hookworms, Trichuris trichiura, Taenia spp, Salmonella and E. coli. The results of this study will assist in modifying the management of EcoSan latrines and use of sludge which may impact the prevalence of excreta related diseases like STHs infection which have been reported as $16.5 \%$ in urban and $3.6 \%$ in rural areas among children aged 3 to 14 years in southern Malawi ${ }^{27}$. The study will also assist in understanding the factors that lead to survival of pathogens in EcoSan and hence assist in reducing the health risk of using EcoSan sludge which have been found to be above WHO recommendation ${ }^{28}$.

\section{Methods}

An observational longitudinal study was done. The observational design helped to understand what happens in

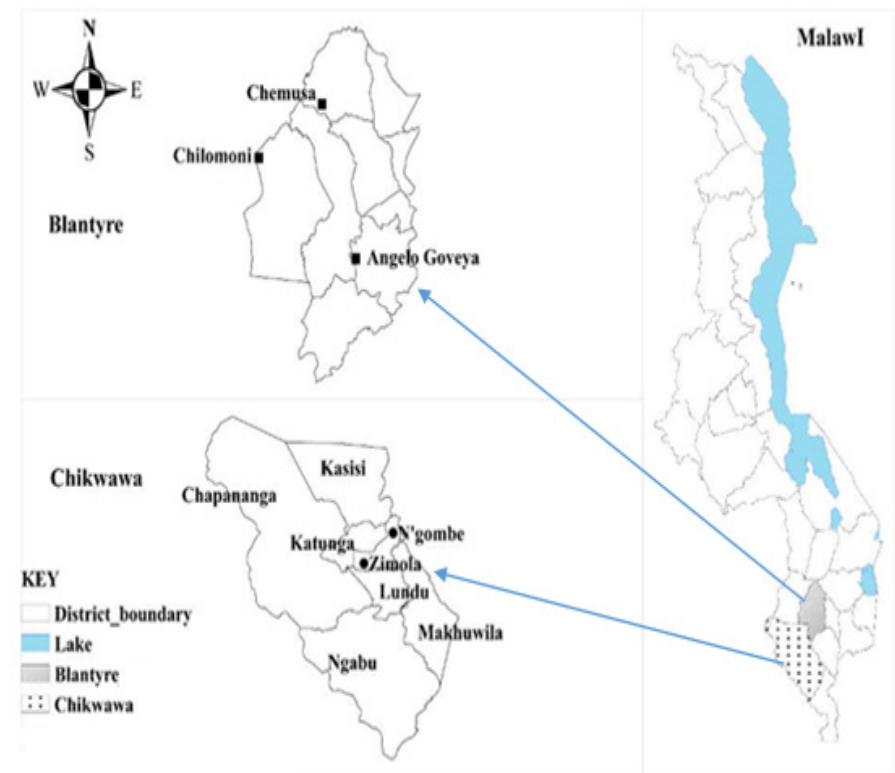

Figure 1: Map of Malawi showing study areas (Map drawn using ArcGIS). Blantyre and Chikwawa offer different climates for this study due to their variations in altitude. ${ }^{29}$

latrines in real life situations as compared to experimental study. EcoSan latrines were followed for a period of twelve months from August 2015 to July 2016 in Blantyre and Chikwawa Districts respectively (Figure 1).

\section{Sample size estimation}

The sample size was estimated based on previous studies done in Malawi which found that the mean helminth concentration was 60 viable eggs per gram of EcoSan sludge (S.D. $=38.5$ helminth eggs per gram $)^{4}$. Using STATA's test for two means with repeated measures and setting power at $80 \%, \alpha=0.05$, the minimum number of latrines in each location was estimated at 16 . Since EcoSan latrines were few in the study areas, all eligible latrines were enrolled. In total, 51 latrines, 18 in Chikwawa and 33 in Blantyre were enrolled. The latrines enrolled had soil and ash for use after defaecation. Owners were encouraged to continue using ash and soil during the study period.

\section{Sample collection}

Samples were collected five times in a single latrine during the months of July and November in 2015 and February, May and July in 2016. The samples collected were examined for helminths, Salmonella and E. coll. The identification of latrines was done with the help of Non-Governmental Organizations (NGOs) who were promoting these latrines in the areas selected for the study. Purposive sampling was done due to the low number of EcoSan latrines in Malawi $(0.3 \%)^{15}$. Eligible latrines were those that were currently in use and due to be sealed within a month from the time of the sampling. Samples during latrine use were collected from the latrine by scooping up to a depth of $30 \mathrm{~cm}$. Each sample weighed 200 to 300 grams. One sampler was used and disinfected after sampling each latrine. One sample was collected from each latrine at a time. Samples were labelled and transported to laboratory within three hours of collection where they were placed in a refrigerator at $40^{\circ} \mathrm{C}$ and processed within 24 hours. Follow-up samples were collected after a latrine 
was sealed within two weeks after the first sampling. The cover was removed, and the contents were sampled from the middle of pit by digging using a hoe. The follow-up samples were collected after 3, 6, 9 and 12 months of sealing the pit. Concentrations of pathogens were measured at baseline in July 2015 (first month of follow-up) and follow up samples were collected after the pits were sealed in November 2015 (5th month), February 2016 (8th month), May 2016 (11th month) and July 2016 (13th month).

\section{Measurement of the microbiological quality of EcoSan sludge}

STHs (A. lumbricoides, Trichuristrichiura, Taenia and hookworms) were measured using a modified triple floatation method ${ }^{30}$. For each latrine sample collected, 20grams was weighed and washed using the ammonium bicarbonate solution. The final sample after washing was kept in a test tube and read under a microscope. STHs eggs were observed to determine their type and viability using morphological characteristics focussing on the shape, size, external layer and the inside of the ova. For E. coli and Salmonella, standard culture methods using Xylose cefixime tellurite sorbitol MacConkey and Lysine Deoxycholate agars were used.31-33 Moisture content was then measured to determine dry weight of the sample.

\section{Moisture content, ammonia and $p H$}

Moisture content was measured by subtracting the weights of EcoSan sludge after heating in the thermocentre oven at $105^{\circ} \mathrm{C}$ for 24 hours from the weight of $20 \mathrm{~g}$ of sludge before heating ${ }^{34}$. Ammonium content was measured using Palintest 1000 series meter ${ }^{34}$. For $\mathrm{pH}$, a 20g sample was weighed and put in a $100 \mathrm{ml}$ beaker to ensure a standard dilution of 1:5. Fifty milliliters $(50 \mathrm{ml})$ of distilled water was added and stirred using a magnetic stirrer for 10 minutes. The $\mathrm{pH}$ was then measured using calibrated METROHM 604 pH meter ${ }^{35}$.

\section{Data analysis}

Longitudinal data analysis techniques for panel data were employed. Since main outcomes were count data (number of viable organisms), Poisson regression was used for both bivariate and multivariate analysis. The associations between pathogen die-off and time and place were evaluated. Bivariate Poisson regression was used to determine significant variables to be included in the model. Multivariate Poisson regression was also used to assess the association between pathogen concentration in samples examined after 12 months of follow-up and $\mathrm{pH}$, ammonia and moisture content ${ }^{23,36}$. Association at $\mathrm{p}<0.05$ were taken to be significant.

\section{Ethical considerations}

Ethical approval was obtained from College of Medicine Research Ethics Committee (COMREC) number P.04/14/1565. The approval was obtained in October 2014. A written informed consent form translated in local language (Chichewa) was administered and signed by the household head where a latrine was selected for inclusion in the study.

\section{Results}

\section{Description of sample and drop-outs}

Fifty-one (51) EcoSan latrines were enrolled (18 FAs in Chikwawa and 33 UDDLs in Blantyre) and sampled at baseline before sealing. Return visits for follow-up samples was done at 3, 6, 9 and 12 months. A complete data set for all sampling times was achieved for 35 latrines (Chikwawa = 13; Blantyre $=22$ ). Resampling was affected by lack of owner availability, and unwillingness to open sealed latrines for subsequent sampling. Latrines with full data were included in the results. All latrines with missing data were removed and regarded as drop-outs.

\section{Prevalence during the follow up period}

Table 1 shows the prevalence in July 2015 (baseline), November 2015, February 2016, May 2016 and July 2016 (end time).

Table 1: Percentage (number) of latrines with E. coli, Salmonella, A. lumbricoides, hookworms and Taenia in Chikwawa

\begin{tabular}{|l|l|l|l|l|l|}
\hline Organism & Jul-15 & Nov-15 & Feb-16 & May-16 & Jul-16 \\
\hline E. coli & $77 \%(10)$ & $77 \%(10)$ & $100 \%(13)$ & $92 \%(12)$ & $92 \%(12)$ \\
\hline Salmonella & $23 \%(3)$ & $38 \%(5)$ & $46 \%(6)$ & $46 \%(6)$ & $62 \%(8)$ \\
\hline Hookworm & $31 \%(4)$ & $62 \%(8)$ & $92 \%(12)$ & $85 \%(11)$ & $85 \%(11)$ \\
\hline A. lumbricoides & $54 \%(7)$ & $46 \%(6)$ & $46 \%(6)$ & $38 \%(5)$ & $31 \%(4)$ \\
\hline Taenia & $8 \%(1)$ & $15 \%(2)$ & $38 \%(5)$ & $23 \%(3)$ & $23 \%(3)$ \\
\hline
\end{tabular}

Apart from A. lumbricoides which showed a decreasing trend in the number of latrines with viable eggs in their sludge, all other organisms did not show any trend. The number of latrines with E. coli, Salmonella, hookworm and Taenia increased if we compare the prevalence at the beginning of the study to the results at the end of the study (Table 1).

Table 2: Percentage (number) of latrines with $E$. coli, Salmonella, A. lumbricoides, hookworms and Taenia in UDDLs

\begin{tabular}{|l|l|l|l|l|l|}
\hline Organism & Jul-15 & Nov-15 & Feb-16 & May-16 & Jul-16 \\
\hline E. coli & $77 \%(17)$ & $82 \%(18)$ & $91 \%(20)$ & $82 \%(18)$ & $86 \%(19)$ \\
\hline Salmonella & $18 \%(4)$ & $68 \%(15)$ & $59 \%(13)$ & $77 \%(17)$ & $68 \%(15)$ \\
\hline Hookworm & $68 \%(15)$ & $64 \%(14)$ & $77 \%(17)$ & $86 \%(19)$ & $91 \%(20)$ \\
\hline A. lumbricoides & $50 \%(11)$ & $55 \%(12)$ & $59 \%(13)$ & $50 \%(11)$ & $41 \%(9)$ \\
\hline
\end{tabular}

A decreasing trend was observed in the number of latrines with viable Taenia in their sludge in UDDLs while in FAs, no trend was observed. Despite showing a reduction in number of latrines with viable $A$. lumbricoides eggs in their sludge during the last month of follow-up as compared to the first, the number increased in November, 2015 and February, 2016 (Table 2). Combined data for the two geographical locations show an increase of hookworm prevalence from 54\% to $89 \%$ while those with $A$. lumbricoides in their sludge decreased from $50 \%$ to $37 \%$. District specific data show a greater decrease in number of latrines with viable $A$. lumbricoides eggs in Chikwawa than in Blantyre. The number of latrines with colony forming units for E. coli and Salmonella increased compared to baseline results for July, 2015 (Tables 1 and 2).

\section{Pathogen concentration in EcoSan latrines during the 12 months follow up period}

Table 3 show the concentration of pathogens in EcoSan sludge from latrines in both Chikwawa and Blantyre. The units for bacterial pathogens was colony forming units per 
gram (cfus/g) while that for helminths was viable eggs per gram (eggs/g) of sludge.

Table 3: Mean pathogen concentration per gram of pit humus

\begin{tabular}{|l|l|l|l|l|l|}
\hline Organism & Jul-15 & Nov-15 & Feb-16 & May-16 & Jul-16 \\
\hline $\begin{array}{l}\text { E. coli } \\
\text { (cfus/g) }\end{array}$ & 2714.9 & 2031.9 & 2832.5 & 1211.2 & 910.0 \\
\hline $\begin{array}{l}\text { Salmonella } \\
\text { (cfus/g) }\end{array}$ & 70.7 & 181.5 & 150.0 & 409.5 & 456.0 \\
\hline $\begin{array}{l}\text { A. lum- } \\
\text { bricoides } \\
\text { (eggs/g) }\end{array}$ & 1.5 & 2.3 & 1.2 & 0.9 & 0.4 \\
\hline $\begin{array}{l}\text { Hook- } \\
\text { worms } \\
\text { (eggs/g) }\end{array}$ & 9.8 & 8.1 & 9.4 & 7.2 & 7.0 \\
\hline $\begin{array}{l}\text { Taenia } \\
\text { (eggs/g) }\end{array}$ & 0.7 & 0.7 & 0.4 & 0.3 & 0.3 \\
\hline
\end{tabular}

The average concentrations of all pathogens investigated reduced over the 12 month follow-up period except for Salmonella which increased after the follow-up period. $A$. lumbricoides, increased to 2.3 viable eggs during the second sampling and then decreased to 0.4 viable eggs per gram after 12 months of follow-up. During baseline, 48\% (24) of EcoSan latrines had more than 1 viable egg per gram while after 12 months of follow-up; only 12\% (6) had more than 1 viable eggs of A. lumbricoides per gram (Table 3 ). The US EPA 1997 standard for Helminths is that pit humus should contain less than 1 viable egg per gram, for Salmonella there should be no detectable colonies per 50 grams while for $E$. coli, it's no more than 100 MPN.11

\section{Predictors of Pathogen concentration in EcoSan sludge}

The dependent variables were concentration of pathogens while type of EcoSan latrine (location) and time in months were the independent variables. All significant dependent variables after a bivariate Poisson regression were put in a multivariate Poisson model and results are presented in Table 4. A p-value of less than 0.05 shows that there is an association between the pathogen concentration and the predictor variable. In case of coefficients, for a oneunit change in the predictor variable, the difference in the logarithm of expected counts is expected to change by the respective regression coefficient, if the other predictor variables in are held constant. Type of latrine and location were not significant predictors of helminths concentration ( $p>0.05)$. However, Salmonella and E. coli colonies were significantly higher in Blantyre (UDDLs) than Chikwawa (FAs) $(\mathrm{p}<0.05)$ (Table 4).

A unit increase in storage time in months led to the decrease in log count of E. coli colonies, A. lumbricoides, hookworms and Taenia eggs per gram of sludge. Time in months was the only consistent predictor for the concentration of helminths.

Factors affecting the pathogen levels in the EcoSan sludge after 12 months of follow-up

After twelve months of follow-up, the EcoSan sludge was ready to be applied in the gardens. The laboratory results for the last follow-up sample was analysed separately to see the predictors of the concentration of pathogens. The
Table 4: Multivariate analysis of pathogen concentration, time and type of EcoSan latrine (location) of the EcoSan latrine

\begin{tabular}{|c|c|c|c|c|}
\hline Pathogen & Factor & Coefficient & $\begin{array}{l}\text { Standard } \\
\text { error }\end{array}$ & P-value \\
\hline \multirow[t]{2}{*}{ E. coli } & \begin{tabular}{|l|}
$\begin{array}{l}\text { Time } \\
\text { (months) }\end{array}$ \\
\end{tabular} & -0.478 & 0.024 & $<0.001$ \\
\hline & $\begin{array}{l}\text { EcoSan type } \\
\text { (Location) }\end{array}$ & -0.265 & 0.099 & 0.008 \\
\hline \multirow[t]{2}{*}{ Salmonella } & $\begin{array}{l}\text { Time } \\
\text { (months) }\end{array}$ & 0.431 & 0.060 & $<0.001$ \\
\hline & \begin{tabular}{|l}
$\begin{array}{l}\text { EcoSan type } \\
\text { (Location) }\end{array}$ \\
\end{tabular} & 0.937 & 0.263 & $<0.001$ \\
\hline \multirow[t]{2}{*}{$\begin{array}{l}\text { Hook- } \\
\text { worms }\end{array}$} & $\begin{array}{l}\text { Time } \\
\text { (months) }\end{array}$ & -0.046 & 0.033 & $<0.001$ \\
\hline & $\begin{array}{l}\text { EcoSan type } \\
\text { (Location) }\end{array}$ & -0.270 & 0.142 & 0.88 \\
\hline \multirow[t]{2}{*}{$\begin{array}{l}\text { A. lumbri- } \\
\text { coides }\end{array}$} & \begin{tabular}{|l|}
$\begin{array}{l}\text { Time } \\
\text { (months) }\end{array}$ \\
\end{tabular} & -0.567 & 0.105 & $<0.001$ \\
\hline & $\begin{array}{l}\text { EcoSan type } \\
\text { (Location) }\end{array}$ & 0.328 & 0.309 & 0.288 \\
\hline \multirow[t]{2}{*}{ Taenia } & \begin{tabular}{|l} 
Time \\
(months)
\end{tabular} & -0.337 & 0.120 & 0.005 \\
\hline & $\begin{array}{l}\text { EcoSan type } \\
\text { (Location) }\end{array}$ & -0.134 & 0.572 & 0.814 \\
\hline
\end{tabular}

mean concentration of pathogens and moisture content, ammonia and $\mathrm{pH}$ measured in the sample collected after 12 months of follow-up are summarized in Table 5.

Table 5: Summary table for pathogen levels and mean ammonia, moisture content and $\mathrm{pH}$ levels after 12 months of follow-up

\begin{tabular}{|l|l|l|l|}
\hline Parameter & $\begin{array}{l}\text { FA (Chikwa- } \\
\text { wa) }\end{array}$ & $\begin{array}{l}\text { UDDL (Blan- } \\
\text { tyre) }\end{array}$ & P-value \\
\hline $\begin{array}{l}\text { A. lum- } \\
\text { bricoides } \\
\text { (eggs/g) }\end{array}$ & 0.38 & 0.41 & 0.54 \\
\hline $\begin{array}{l}\text { Hookworm } \\
\text { (eggs/g) }\end{array}$ & 10.15 & 5.14 & 0.04 \\
\hline $\begin{array}{l}\text { Taenia } \\
\text { (eggs/g) }\end{array}$ & 0.31 & 0.27 & 0.44 \\
\hline E. coli (cfus/g) & 1007.69 & 859.09 & 0.36 \\
\hline $\begin{array}{l}\text { Salmonella } \\
\text { (cfus/g) }\end{array}$ & 346.15 & 509.09 & 0.76 \\
\hline $\begin{array}{l}\text { Moisture con- } \\
\text { tent (\%) }\end{array}$ & 13.38 & 11.91 & 0.17 \\
\hline $\begin{array}{l}\text { Ammonia } \\
\text { (mg/l) }\end{array}$ & 84.15 & 91.86 & 0.78 \\
\hline pH & 8.92 & 8.68 & 0.27 \\
\hline
\end{tabular}

The samples had a mean of less than one viable egg per gram for $A$. lumbricoides and Taenia. Hookworm concentration were at 10.15 viable eggs per gram in FAs and 5.14 viable eggs per gram for UDDLs (Table 5).

\section{Predictors of pathogen concentration in EcoSan sludge after 12 months of storage}

The results from Table 3 show that Taenia and $A$. lumbricoides concentration was not related to moisture content, $\mathrm{pH}$, 
Table 6: Multivariate analysis for pathogens and moisture content, ammonia and $\mathrm{pH}$ for FAs (Chikwawa) and pathogen content in relation to moisture content and $\mathrm{pH}$ for UDDLs (Blantyre)

\begin{tabular}{|c|c|c|c|c|c|c|c|}
\hline \multirow[b]{2}{*}{ Pathogen } & \multirow[b]{2}{*}{ Factor } & \multicolumn{3}{|c|}{ FAs (Chikwawa) } & \multicolumn{3}{|c|}{ UDDLs (Blantyre) } \\
\hline & & Coefficient & $\begin{array}{l}\text { Standard } \\
\text { Error }\end{array}$ & P-Value & Coefficient & $\begin{array}{l}\text { Standard } \\
\text { Error }\end{array}$ & P-Value \\
\hline \multirow[t]{2}{*}{ E. coli } & $\begin{array}{l}\text { Moisture } \\
\text { content }\end{array}$ & 0.031 & 0.011 & 0.004 & -0.090 & & $<0.001$ \\
\hline & $\mathrm{pH}$ & 0.220 & 0.105 & 0.04 & 0.388 & & $<0.001$ \\
\hline \multirow[t]{3}{*}{$\begin{array}{l}\text { Salmo- } \\
\text { nella }\end{array}$} & $\begin{array}{l}\text { Moisture } \\
\text { content }\end{array}$ & - & - & - & -0.090 & 0.020 & $<0.001$ \\
\hline & Ammonia & 0.052 & 0.016 & 0.001 & - & - & - \\
\hline & $\mathrm{pH}$ & - & - & - & 0.388 & 0.090 & $<0.001$ \\
\hline
\end{tabular}

ammonia in FAs and moisture content and $\mathrm{pH}$ in UDDLs. E. coli was predicted by $\mathrm{pH}$ and moisture content in both FAs and UDDLs, Salmonella was predicted by ammonia in FAs while in UDDLs, it was predicted by moisture content and $\mathrm{pH}$ (Table 6). Hookworm, A. lumbricoides and Taenia concentration were left out because they showed no significant relationships with all predictors under consideration during a bivariate Poisson regression. The residual $\mathrm{pH}$, moisture content and ammonia were unable to predict the concentration of helminths in the sample after 12 months of storage.

\section{Discussion}

Despite showing a reduction in mean concentration of hookworm eggs per gram of sludge, the number of latrines with the helminths in their sludge increased. This might be due to high prevalence of hookworms in the population and the poor practices of households members in terms of management of stored sludge leading to contamination ${ }^{14}$. A. lumbricoides showed a decrease in both number of viable eggs per gram and number of EcoSan latrines with the helminth during the follow-up period. In terms of helminths, it was only the hookworm that was above the recommended guidelines for use of excreta ${ }^{10}$. A. lumbricoides despite being an indicator organism ${ }^{25}$, was unable to predict the concentration of hookworm which is less resistant to environmental conditions than $A$. lumbricoides. The absence of A. lumbricoides meant that other less resistant helminths were also supposed to be inactivated before $A$. lumbricoides but this was not the case. This could be because of the high levels of environmental contamination due to poor hygiene practices.

It was found that pathogen concentrations were significantly related to time in months. As storage time increased, there was a reduction in log concentration of pathogens per gram of sludge. FA rely on ammonia from urine and $\mathrm{pH}$ from the ash added after use to kill pathogens while UDDLs mainly depend on drying the pit contents and increase in $\mathrm{pH}$ to sanitize pit contents. Moisture content, $\mathrm{pH}$ and ammonia were measured in the samples from FAs while moisture content and $\mathrm{pH}$ were determined from samples from UDDLs. The level of moisture content in the last sample taken in July, 2016 was within the recommended level of less than $25 \%$ as stipulated in the WHO guideline for use of excreta after more than 6 months of storage ${ }^{37}$. However, the moisture content was greater than the United States Environmental Protection Agency standard of 1992 which states that it should be less than $5 \% .38$ The mean $\mathrm{pH}$ for Chikwawa and Blantyre respectively were lower than the effective $\mathrm{pH}$ of more than 12. Ammonia only reached an average of at most $92 \mathrm{mg} / 1$ instead of the recommended concentration of

$280 \mathrm{mg} / 1.3{ }^{38}$ Despite finding ammonia content and $\mathrm{pH}$ for the two types of latrines (locations) below the effective level for pathogen die-off, we could not tell if levels were high during other months where these parameters were not measured.

A multivariate analysis was performed to assess the factors that predict the concentration of pathogens in the final sample. Moisture content and $\mathrm{pH}$ were able to predict concentration of E. coli and Salmonella while no factor was related to helminths' concentration in the last sample. Though moisture content, $\mathrm{pH}$ and ammonia have proved to be important factors for the inactivation of helminths, their effect on hookworms, A. lumbricoides and Taenia was not significant partly because the recommended minimum levels for rapid inactivation of $5 \%, 12$ and $280 \mathrm{mg} / 1$ respectively were not reached ${ }^{3,38}$. Inconsistent use of ash was also suspected to be the main reason for lower $\mathrm{pH}$ levels as indicated in an earlier study ${ }^{14}$. Environmental factors including $\mathrm{pH}$, temperature, humidity, moisture content and ammonia might not have reached lethal levels for pathogen die-off during the other months where these parameters were not monitored, therefore, it was difficult to conclude any relationship to pathogen concentration.

Since all FAs and UDDLs were from Chikwawa and Blantyre respectively, it was impossible to compare between same types of latrine within the same location. Lack of control made it difficult to explain how the prevalence of viable helminths eggs increased in sludge between November 2015 and February 2016. Observational studies fail to control extraneous factors which may obscure the effect of temperature and humidity ${ }^{39}$. Despite the limitations, the paper provides important information in the field of ecological sanitation that will help decision makers in their planning process and provides areas for improvements in further research.

\section{Conclusion}

In uncontrolled environments where compliance to EcoSan guidelines were not guaranteed, type of EcoSan latrine and time in months were related to the concentration of pathogens in EcoSan sludge. No factor was a consistent predictor for the concentration of helminths in the last sample collected after 12 months of follow-up. The study also concluded that $A$. lumbricoides may not be the 
main indicator organism for safety of sludge where other helminths are highly prevalent causing a public health risk and we recommend use of total helminths as outlined in the WHO and US EPA guidelines as a measure of sludge safety. Since EcoSan sludge has been found to still contain high Hookworm eggs, E. coli and Salmonella even after the waiting period of more than 12 months, protection during handling and use in agriculture is important. Storage time of 12 months or more is recommended.

\section{Acknowledgements}

Authors would like to acknowledge the contribution of $\mathrm{Mr}$. Yohane Diness and Jacqueline Chimkwita-Phiri, interns at the University of Malawi, College of Medicine in Malawi, for their assistance during data collection. I am also grateful to Dr. Elizabeth Tilley from the University of Malawi, ThePolytechnic, for assisting in proofreading this manuscript.

\section{Authors' contributions}

Save Kumwenda conceptualized the research, took part in data collection, analysed the data and drafted the initial manuscript; Chisomo Msefula revised the research idea, assisted in drafting and revising the manuscript; Wilfred Kadewa assisted in conceptualization of the research idea, assisted in drafting and revising the manuscript; Davis Makupe assisted in data analysis and assisted in writing and revising the manuscript; Bagrey Ngwira took part in conceptualizing the research and revising the manuscript; Tracy Morse took part in conceptualizing the research, drafting and revising the manuscript.

\section{Funding}

This work was supported by Consortium for Advanced Research Training in Africa (CARTA). CARTA is jointly led by the African Population and Health Research Center and the University of the Witwatersrand and funded by the Wellcome Trust (UK) (Grant No. 087547/Z/08/Z), the Carnegie Corporation of New York (Grant No--B 8606. R02), Sida (Grant No:54100029). The statements made and views expressed are solely the responsibility of the author. The other support came from Southern African Consortium for Research Excellence (SACORE).

\section{Availability of data and materials}

The datasets generated during and/or analysed during the current study are available from the corresponding author on reasonable request.

\section{Competing interests}

The authors declare no competing interests.

\section{References}

1. Joelsson A-E. Composting of human excreta with Howard-Higgins composting method [Internet] [MSc Thesis]. [Uppsala, Sweden]: Department of energy and Technology, SLU; 2013 [cited 2018 Aug 11]. Available from: http://www.diva-portal.se/smash/get/diva2:622330/ FULLTEXT01.pdf

2. Austin A. Health aspects of ecological sanitation. In: Abstract Volume, First International Conference on Ecological Sanitation [Internet]. 2002, p. 104-111 [cited 2013 Apr 24]. Available from: http://www.ecosanres. org/pdf_files/Nanning_PDFs/Eng/Aussie\%20Austin\%2028_E25.pdf 3. McKinley JW, Parzen RE, Guzmán ÁM. Ammonia inactivation of Ascaris ova in ecological compost by using urine and ash. Appl Environ Microbiol. 2012;78(15):5133-5137. doi: 10.1128/AEM.00631-12
4. Morgan P, Mekonnen A Tesfaye. Paving the Way to Scaling Up Ecosan in Malawi [Internet]. Share research. 2013 [cited 2013 Apr 30]. Available from: http://www.shareresearch.org/LocalResources/ Morgan_and_Mekonnen_2013_Paving_the_Way_to_Scaling_Up_ Ecosan.pdf

5. Pecson BM, Barrios JA, Jiménez BE, Nelson KL. The effects of temperature, $\mathrm{pH}$, and ammonia concentration on the inactivation of Ascaris eggs in sewage sludge. Water Res. 2007 (13):2893-2902. doi: 10.1016/j.watres.2007.03.040

6. National Research Council (US) Subcommittee on Microbiological Criteria. Selection of Indicator Organisms and Agents as Components of Microbiological Criteria [Internet]. Washington (DC): National Academies Press (US); 1985 [cited 2018 Jul 31]. Available from: https://www.ncbi.nlm.nih.gov/books/NBK216669/

7. World Health Organisation. Soil-transmitted helminth infections [Internet]. World Health Organization. 2018 [cited 2018 Jun 3]. Available from: http://www.who.int/news-room/fact-sheets/detail/soiltransmitted-helminth-infections

8. Pullan RL, Brooker SJ. The global limits and population at risk of soil-transmitted helminth infections in 2010. Parasit Vectors. 2012;5:81. doi: 10.1186/1756-3305-5-81

9. World Health Organisation. Soil-transmitted helminth infections [Internet]. World Health Organization. 2016 [cited 2016 Oct 27]. Available from: http://www.who.int/mediacentre/factsheets/fs366/en/ 10. World Health Organization. Guidelines for the safe use of wastewater, excreta and greywater. [Internet]. Geneva: World Health Organization; 2006 [cited 2013 Jul 22]. Available from: http://apps. who.int/iris/bitstream/handle/10665/78265/9241546824

11. Environment Protection Authority. Use and disposal of biosolids products. [Internet]. Chatswood, N.S.W.: Environment Protection Authority; 1997 [cited 2016 May 9]. Available from: http://www.epa. nsw.gov.au/resources/water/BiosolidsGuidelinesNSW.pdf

12. Ministry of Irrigation and Water Development. Low cost Latrine Technologies. Ministry of Irrigation and Water Development; 2011.

13. Schuen R, Parkinson J. Study for Financial and Economic Analysis of Ecological Sanitation in Sub-Saharan Africa [Internet]. Nairobi, Kenya: Water and Sanitation Program; 2009 [cited 2012 Oct 23]. Available from: www.wsp.org/UserFiles/file/Ecosan_Report.pdf

14. Kumwenda S, Msefula C, Kadewa W, Ngwira B, Morse T, Ensink JHJ. Knowledge, attitudes and practices on use of Fossa Alternas and double vault urine diverting dry (DVUDD) latrines in Malawi. J Water Sanit Hyg Dev. 2016; 6 (4): 555-568. doi: 10.2166/washdev.2016.177. 15. National Statistical Office, ICF International. Malawi Demographic and Health Survey 2015-16 [Internet]. Zomba, Malawi, and Rockville, Maryland, USA.: NSO and ICF International; 2016 [cited 2016 Jun 14]. Available from: http://www.dhsprogram.com/pubs/pdf/PR73/PR73.pdf 16. Ministry of Health. National Health Research Agenda [Internet]. The Government of Malawi, Lilongwe, Malawi; 2012 [cited 2013 Apr 26]. Available from: https:/www.ncst.mw/wp-content/uploads/2016/01/ National-Health-Research-Agenda-NHRA.pdf

17. Itchon GS, Holmer RJ, Tan MLB. The public health safety of using human excreta from urine diverting toilets for agriculture: the Philippine experience. IN: Shaw, R.J. (ed). Water, sanitation and hygiene Sustainable development and multisectoral approaches: Proceedings of the 34th WEDC International Conference, Addis Ababa, Ethiopia, 1822 May 2009, 8p.p. [cited 2013 May 11]. Available from: https://dspace. lboro.ac.uk/dspace-jspui/bitstream/2134/29548/3/Itchon_G_-_25.pdf 18. Mehl JA. Pathogen destruction and aerobic decomposition in composting latrines: A study from rural panama [Internet]. Michigan Technological University; 2008 [cited 2014 May 12]. Available from: http://cee.eng.usf.edu/PeaceCorps/5\%20-\%20Resources/Theses/ Sanitation/2008Mehl.pdf

19. Morgan P. Ecological Sanitation, The toilet that makes humus: An account of the Fossa alterna system and its usefulness in rural and usefulness in rural and peri-urban communities [Internet]. Sustainable Sanitation and Water Management (SSWM); 2004 [cited 2016 Dec 4]. Available from: http://www.sswm.info/sites/default/files/reference attachments/the-toilet-that-makes-humus.PDF

20. Jiménez B. Pathogens in dry sanitation systems and risk of using sludge in agriculture. In Instituto de Ingeniería, Universidad Nacional Autónoma de México Apdo Postal 70472; Ciudad Universitaria; 04510 
Coyocan DF, Mexico; 2009. Available from: https://www.researchgate. net/publication/228543468

21. Hawksworth D, Archer C, Rajcoomar K, Buckley C, Stenström TA. The Effect of Temperature and Relative Humidity on the Viability of Ascaris Ova in Urine Diversion Waste. Pollution Research Group, University of KwaZulu-Natal, Howard College Campus, Durban 4041, South Africa (unpublished)

22. Jensen PK, Phuc PD, Konradsen F, Klank LT, Dalsgaard A. Survival of Ascaris eggs and hygienic quality of human excreta in Vietnamese composting latrines. Environ Health. 2009;1:57. doi: 10.1186/1476069X-8-57.

23. Magri ME, Philippi LS, Vinnerås B. Inactivation of pathogens in feces by desiccation and urea treatment for application in urinediverting dry toilets. Appl Environ Microbiol. 2013;79(7):2156-2163. doi: 10.1128/AEM.03920-12

24. Holmqvist A, Stenström TA. Survival of Ascaris suum ova, indicator bacteria and Salmonella typhimurium phage $28 \mathrm{~B}$ in mesophilic composting of household waste. In: Abstract Volume, First International Conference on Ecological Sanitation [Internet]. 2001 [cited 2013 Apr 24]. p. 99-103. Available from: http://www.ecosanres. org/pdf_files/Nanning_PDFs/Eng/Annika\%20Holmqvist $\% 20$ et $\% 20$ al\%20\%2027_E36.pdf

25. Nordin A, Niwagaba $\mathrm{C}$, Jönsson H, Vinnerås B. Pathogen and indicator inactivation in source-separated human urine heated by the sun. J Water Sanit Hyg Dev. 2013;3(2):181. doi:10.2166/washdev.2013.174 26. Nordin A, Nyberg K, Vinnerås B. Inactivation of Ascaris Eggs in Source-Separated Urine and Feces by Ammonia at Ambient Temperatures. Appl Environ Microbiol. 2008;5;75(3):662-7. doi: 10.1128/AEM.01250-08

27. Phiri K, Whitty CJ, Graham SM, Ssembatya-Lule G. Urban/ rural differences in prevalence and risk factors for intestinal helminth infection in southern Malawi. Ann Trop Med Parasitol. 2000;94(4):381387. doi: 10.1080/00034983.2000.11813553

28. Kumwenda S, Msefula C, Kadewa W, Ngwira B, Morse T. Estimating the Health Risk Associated with the Use of Ecological Sanitation Toilets in Malawi. J Environ Public Health. 2017:1-13. doi: $10.1155 / 2017 / 3931802$

29. Department of Climate Change and Meteorological Services [Internet]. Malawi. Meteorological data 2016 [cited 2016]. Available from http://www.metmalawi.com

30. Moodley P, Archer C, Hawksworth D, Leibach L. Water Research Commission. Standard methods for the recovery and enumeration of helminth ova in wastewater, sludge, compost and urine-diversion waste in South Africa: report to the Water Research Commission. Gezina: Water Research Commission; 2008.

31. Rashid N, Misbahuddin M, Choudhry ZK, Saleh AA, Sattar NI. The colony count of Escherichia coli in the stool of palmar arsenical keratosis following probiotics supplementation. Bangladesh J Pharmacol. 2014; 9(2): 176-181. doi:10.3329/bjp.v9i2.17168

32. Petersen J. Isolation, identification and serotyping of Salmonella from faeces and food [Internet]. World Health Organization; 2003 [cited 2018 Apr 8]. Available from: https://pdfs.semanticscholar.org/0266/ aa432cbbf6641ee25e5d0d8a7d05c832ccea.pdf

33. Centre for Disease Control. E. coli O157:H7: Procedure for Isolation and Identification from stool specimens [Internet]. Centre for Disease Control and Prevention. 1998 [cited 2018 Aug 4]. Available from: https://wonder.cdc.gov/wonder/prevguid/p0000445/p0000445.asp

34. Hach Company. DR/850 Colorimeter Procedures Manual [Internet]. 2013 [cited 2016 May 20]. Available from: www.hach.com/asset-get. download.jsa?id=7639982342

35. Metrohm. $\mathrm{pH}$, ion, and conductivity measurement [Internet]. [cited 2017 Dec 3]. Available from: https://www.metrohm.com/en/products/ ph-ion-measurement/

36. Gardner W, Mulvey EP, Shaw EC. Regression analyses of counts and rates: Poisson, overdispersed Poisson, and negative binomial models. Psychol Bull. 1995;118(3):392-404. doi: 10.1037/00332909.118.3.392

37. Petterson SA, Ashbolt NJ. WHO guidelines for the safe use of wastewater and excreta in agriculture [Internet]. 2005 [cited 2016 Jun 5]. Available from: http://citeseerx.ist.psu.edu/viewdoc/ download?doi=10.1.1.471.8530\&rep=rep1\&type $=$ pdf

38. United States Environmental Protection Agency. Guidelines for Exposure Assessment [Internet]. U.S. Environmental Protection Agency Washington, DC; 1992 [cited 2016 Aug 11]. Available from: http://www.iaea.org/inis/collection/NCLCollectionStore/ Public/27/056/27056989.pdf\#page $=2$

39. Thompson CB, Panacek EA. Research study designs: Nonexperimental. Air Med J. 2007;26(1):18-22. doi: 10.1016/j. amj.2006.10.003 